\title{
FIGURATIVE LANGUAGE IN ENGLISH STAND-UP COMEDY
}

\author{
Maharani Widya Putri \\ Department of English Education, University of Kuningan, Indonesia \\ Email: putrimaharaniwidya@gmail.com \\ Erwin Oktoma \\ Department of English Education, University of Kuningan, Indonesia \\ Email: oktoma09erwin@yahoo.com \\ Roni Nursyamsu \\ Department of English Education, University of Kuningan, Indonesia \\ Email: roninursyamsu@gmail.com
}

APA Citation: Putri, M. W., Oktoma, E., \& Nursyamsu, R. (2016). Figurative language in English stand-up comedy. English Review: Journal of English Education, 5(1), $115-130$

\begin{abstract}
This descriptive qualitative research was about the analysis of figurative language in English stand-up comedy. The purposes of this study were to identify the types of figurative language and to describe the functions of figurative language found in the selected video of stand-up comedy show. The data source was taken from one of selected videos of Russell Peters stand-up comedy show. Russell Peters's speech contained about figurative language in the video is observed. The data were collected through content analysis technique by collecting the verbal language used by Russell Peters. The first research questions was analyzed by McArthur (1992) theory and supported by Crystal (1994) theory to find out the types of figurative language found in English stand-up comedy. To answer the second research questions about the functions of figurative language found in English stand-up comedy was analyzed by Chunqi (2014) theory and suppoted by Kokemuller (2001) theory and Turner (2016) theory. After analyzing data, it was found that Irony was the most dominant figurative language used by Russell Peters in "Russell Peters Comedy Now! Uncensored" with 29.94\%. It was happened because the kind of topics used by Russell Peters in that show were about ethnics (canadian, white people, black people, brown people and asian), society case (beating child) and culture (accent and life style of various ethnics in the world, habitual of various ethnics in the world). Irony and Hyperbole were needed dominantly in the performance, to entertain the audiences in the stand-up comedy show. The function of eleven types of figurative language which were used by Russell were concluded. The functions were to amuse people in comedic situations, to expand meaning, to explain abstract emotions, to make sentence interesting represented and give creative additions.

Keywords: Figurative Language, Stand-Up Comedy, English Stand-Up Comedy.
\end{abstract}

\section{INTRODUCTION}

It has been known for decades that communication can be done with a process of interaction between sender and listener which uses message and produces feedback. Then, communication also can be done with just a process of transmitting message from the sender to the listener without a feedback. One way communication is 
considered as a special way of communicating because it produced several unique phenomena. Fenner (2003) says that "in one-way communication, information is transferred in one direction only from the sender to the listener." One-way communication is limited because it just occurs in a straight line from sender to listener and get little feedback.

As an example, stand-up comedy represents the unique realization of oneway communication. Astuti, Sada, Wardah $(2013$, p.2) mentions that "...humor and joke transformed into monolog activity and performed which makes any listener and audience enjoy and pleasant that called as stand-up comedy." In monologue activity, a standup comedian talks to express ideas, experiences, feelings, and opinions in his/her mind. Humor can be delivered in particular ways in stand-up comedy. Most of stand-up comedy performance is presented in verbal ways because standup comedian relies their performance on their stories to make audiences interested. In term of the language used by stand-up comedian, Chunqi (2014, p.276) mentions that "...in a stand-up comedian's speech, there are figurative language, word play, puns, implication and allusion as the linguistic aspect to make the performance interesting and funny." Figurative language as one of linguistics aspect make the verbal communication used in stand-up comedy become more interesting and stimulate feedback in the form of laughter.

In the field of semantic study, it is quite ordinary to do a research about figurative language in literary works because it can be found easily. Therefore, conducting a semantic study with different subject becomes very interesting. Stand-up comedy research seems to be important in Indonesia society now. In line with (Papana 2012) as cited in (Fitri, 2013, p.22) states that "stand up comedy has been popular in Indonesia for the last two years, since KOMPAS TV held a stand-up comedy Indonesia competition in September 2011 and brought this comedy show successfully into public." So, if this research can reveal one of unique phenomena in stand-up comedy, this study will be useful for Indonesia society who like watching stand-up comedy.

Based on the background above, the writer would like to answer the following questions: "What are the types of figurative language found in the selected video of Stand-up comedy show?" and "What are the functions of figurative language found in the selected video of Stand-up comedy show?"

Based on the research questions above, the objectives of this research are, as follows: to identify the types of figurative language found in the selected video of Stand-up comedy show and to describe the functions of figurative language found in the selected video of Stand-up comedy show.

\section{METHOD}

Descriptive qualitative method is used in this research. Cresswell (2012, p.247) mentions that, "description involves a detailed rendering of information about people, places, or events in a setting." The types of figurative language in the selected video of Stand-up comedy show are described in detail in this research.

The selected video of Russell Peters stand-up comedy show "Russell Peters Comedy Now! Uncensored" used as the data source in this research. The url of the video is https://www.youtube.com/watch?v=C Pyyt0TmQjk which is published on 
March 11th, 2012. The duration of the video was 00:45:07. Russell Peters's speech which contains about figurative language in the video is observed by the writer.

Based on techniques of collecting data by Kothari (2004, p.110), content analysis is used in this research. Kothari (2004, p.110) states that "the analysis of content is a central activity whenever one is concerned with the study of the nature of the verbal materials." The verbal language used by stand-up comedian in stand-up comedy show is analyzed by the writer to collect the data. The processes in collecting the data are; first, the video is watched by the writer then Russell Peters's speech is transcribed. After that, each of Russell Peters's speech which has an indication to be figurative language is classified.

After finding the occurrences of figurative language in the data source, the first step in the analyzing process to answer research questions is identifying the types of figurative languages found by using the theory of figurative language by McArthur (1992). Crystal's theory (1994) also used to support and to analyze Russell Peters's speech which can't be analyzed by McArthur's theory (1992). From the theory, not only the most dominant figurative language in the selected video of Russell Peters's stand-up comedy show will be shown. But also the functions of figurative language found in the selected video of Russell Peters's stand-up comedy show will be revealed clearly. In order to reveal the function of figurative language found in the selected video of Russell Peters's stand-up comedy show, Chunqi's theory (2014) will be used.

Kokemuller's theory (2001) and Turner's theory (2016) also will be used to support Chunqi's theory (2014).

\section{RESULTS AND DISCUSSION}

After analyzed the data, for the first research question it was answered that there were found 167 (one hundred and sixty seven) utterance contained of figurative language. McArthur (1992) proposed fourteen types of figurative language; Alliteration, Chiasmus, Euphemism, Hyperbole, Idiom, Irony, Litotes, Metaphor, Metonymy, Onomatopoeia, Oxymoron, Paradox, Personification and Simile. In the selected video of Russell Peters stand-up comedy show, it was found eleven types of figurative languages. Each figurative languages types found in the selected video of Russell Peters's stand-up comedy show counted by using frequency of cummulative formula by Subana as cited in (Oktoma, \& Mardiyono, 2013, p. 79).

$$
\text { FK rel }=\frac{F K}{\Sigma F} X 100 \%
$$

Where:

FK = Frequency of cumulative (the number of occurences of figurative language types)

$\Sigma \mathrm{F} \quad=$ Frequency of total (the number of the whole occurences of figurative language types)

FK rel $=$ Frequency of relative cumulative (the result of percentages) Subana as cited in (Oktoma, \& Mardiyono, 2013, p. 79)

The classification and percentage of figurative language used in the video of Russell Peters - Comedy Now! Uncensored (2006) stand-up comedy show could see in the table 4.4 Types of Figurative Language and Occurrences Found in Russell Peters - Comedy Now! Uncensored (2006) below: 
Table 1. Types of Figurative Language and Occurrences Found in Russell Peters - Comedy Now! Uncensored (2006)

\begin{tabular}{cccc}
\hline No. & Figurative language & $\begin{array}{c}\text { Number of } \\
\text { occurrences }\end{array}$ & Percentage \\
\hline 1. & Alliteration & 7 & $4.20 \%$ \\
\hline 2. & Chiasmus & 8 & $4.80 \%$ \\
\hline 3. & Euphemism & - & - \\
\hline 4. & Hyperbole & 40 & $23.95 \%$ \\
\hline 5. & Idiom & 9 & $5.38 \%$ \\
\hline 6. & Irony & 50 & $29.94 \%$ \\
\hline 7. & Litotes & 2 & $1.20 \%$ \\
\hline 8. & Metaphor & 3 & $1.80 \%$ \\
\hline 9. & Metonymy & 18 & $10.77 \%$ \\
\hline 10. & Onomatopoeia & 16 & $9.58 \%$ \\
\hline 11. & Oxymoron & - & - \\
\hline 12. & Paradox & - & - \\
\hline 13. & Personification & 3 & $1.80 \%$ \\
\hline 14. & Simile & 11 & $6.58 \%$ \\
\hline & Total & $\mathbf{1 6 7}$ & $\mathbf{1 0 0} \%$ \\
\hline
\end{tabular}

From the table above, it was shown that in the video of Russell Peters Comedy Now! Uncensored (2006) standup comedy show, there were found 11 (eleven) types of figurative languages. The types were Alliteration, Chiasmus, Hyperbole, Idiom, Irony, Litotes, Metaphor, Metonymy, Onomatopoeia, Personification, and Simile. Euphemism, Oxymoron and Paradox were not found in the video of Russell Peters - Comedy Now! Uncensored (2006) stand-up comedy show.

From the table above, it could be known the number of occurrences of figurative language in the video of Russell Peters - Comedy Now! Uncensored (2006) stand-up comedy show. There were only 167 types of figurative language which were found in the Russell Peters' utterances. There were 7 utterances $(4.20 \%)$ belonging to Alliteration, 8 utterances $(4.80 \%)$ belonging to Chiasmus, 40 utterances (23.95\%) belonging to Hyperbole, 9 utterances (5.38\%) belonging to Idiom, 50 utterances (29.94\%) belonging to Irony, 2 utterances $(1.20 \%)$ belonging to Litotes, 3 utterances $(1.80 \%)$ belonging to Metaphor, 18 utterances (10.77 \%) belonging to Metonymy, 16 utterances $(9.58 \%)$ belonging to Onomatopoeia, 3 utterances $(1.80 \%)$ belonging to Personification and 11 utterances $(6.58 \%)$ belonging to Simile. The most dominant of figurative language was Irony with the number of occurrences was $50(29.94 \%)$. The less figurative language was Litotes with the number of occurrences was $2(1.20 \%)$.

In the video of Russell Peters Comedy Now! Uncensored (2006) standup comedy show, Russell Peters used Irony as the most figurative language used in his show. In his show, Russell wanted to deliver his stories in stand-up comedy in unique way by make an irony statement almost in every utterance. As Chunqi (2014, p.227) states that "irony is often taken as a common and incisive device for amusing people in comedic situations." Hyperbole also took in the 
second place as the most dominant of figurative language use by Russell Peters in 40 utterances (23.95\%). Chunqi (2014, p.227) also adds that "...hyperboles creates a humorous effect by directing a satirical implication at a person who is in a superior social status. By using the hyperboles, the joke becomes indirect and less aggressive in attacking the target." In the video of Russell Peters Comedy Now! Uncensored (2006) standup comedy show, Russell told various topics in society. "Stand-up comedy function not only to entertain people but also to present various current issues and topics ranging from ethnicity, gender, politics, to those considered taboo" (Setyaningsih, 2013, p.145). The topics were about ethnics (canadian, white people, black people, brown people and asian), society case (beating child) and culture (accent and life style of various ethnics in the world, habitual of various ethnics in the world). Russell used irony to express something by using sarcastic expression. "...words with an implication opposite to their usual meaning, ironic comment may be humorous or mildly sarcastic" (McArthur, 1992, p.532). Irony statement was used by Russell to tell about ethnic and culture stories to amuse people in the comedic situations. Hyperbole was used to create an extra effect for comedy statement. "Hyperbole is a rhetorical term for exaggeration or overstatement, usually deliberate and not meant to be taken (too) literally" (McArthur, 1992, p.491). Hyperbole was used by Russell to tell stories about society case. So, Irony and Hyperbole were needed dominantly in the performance, to entertain the audiences in the stand-up comedy show.

To answer the second research question, in order to reveal the function of figurative language found in the video of Russell Peters comedy now! uncensored stand-up comedy show, Chunqi's theory (2014) was used. Kokemuller's theory (2001) and Turner's theory (2016) also was used to support Chunqi's theory (2014). Kokemuller (2001) has given a description about what are the purposes of figurative language in communication.

Figurative language plays a major role in compelling literary works. Figurative language is a contrast to literal language. Its primary purpose is to force readers to imagine or intuit what an author means with an expression or statement. Applying the right element in making specific points in writing is necessary to make figurative language work. Regardless the tool, figurative language strengthens or makes a point more compelling and effective (Kokemuller, 2001).

Chunqi (2014) explains the finding from his journal about the function of figurative language in stand-up comedy. The functions were hyperbole used to exaggerate reality by carrying beyond the boundaries of rational thought, irony was often taken to infer the speaker's intention and to amuse people in comedic situations, the last simile used to make analogy statement in stand-up comedy more interesting and unexpected to the live audience.

In this present study, various types of figurative languages were used because of particular function. The function of figurative language found in the selected Russell's stand-up comedy show presented below:

\section{Alliteration}

The first function of figurative language in stand-up comedy which will be presented is alliteration. Alliteration is sound device in figurative language. "Alliteration is terms in rhetoric, poetics, and general usage for the repetition of 
the same sound, usually an initial consonant such as the/in 'Fixed fate, free will, foreknowledge absolute'" (McArthur, 1992, p.29). In stand-up comedy, alliteration is used to give creative additions. In line with Kokemuller (2001), alliteration is used to give an image in the form of playing sound to deliver stories. By using alliteration in telling the stories, the audiences will think that the stories is more interesting than usual stories because alliteration gives sound phenomenon in communication. One of alliterations which be the sample was:

\section{Utterance 75 (20:17)}

- I went to Italy.. the Italians thought I was Italian.

Russell used the repetition $1 \mathbf{y}$, lians and lians in the word 'italy' in one sentence to give creative additions in telling the stories. As we know, a stand-up comedian used a limited properties in stand-up comedy performance. One of ways that can they use to make their stories is catched by the audiences by playing the word in telling the stories. In the show, Russell wanted to show his skill in telling the stories interesting by making a sentence which full with alliteration word.

\section{Chiamus}

The second function of figurative language in stand-up comedy which will be presented is chiamus.

According to McArthur (1992, p.209)

"chiasmus in rhetoric is an inversion of word order that creates a counterbalancing effect in the second of two linked phrases." Chiasmus is a figure of speech in figurative language which represents word play like alliteration. The differences are alliteration hold the role of figurative language on the same sound or consonant in the word but chiasmus hold the role on the balance structure between two sentences. One of chiasmuses which be the sample was:

\section{Utterance 10 (03:40)}

- "You know, it's not so much a problem. It's a problem if you want it to be problem."

In that sentence, Russell made a sentence or phrase in which the order of some words in the first sentence or phrase is reversed in the sentence or the phrase that follow. The arrangement of words, phrases and clauses were reversed with a phrase or clause that follows. If we heard a stand-up comedian used chiasmus like the exmaple above, it seemed to be more interesting and easy listening because it used balancing structure. In order to make the statement was interesting to speak, chiasmus as one of types in figurative language can be used. The way chiasmus represents two sentences in the complete sentence which has different meaning makes chiasmus can be used to make the word was interesting represented. So, chiamsus used by stand-up comedian to make sentence represented interesting.

\section{Hyperbole}

The third function of figurative language in stand-up comedy which will be presented is hyperbole. In stand-up comedy show, Russell used hyperbole to make a dramatic effect in his utterance because of overstatement word. In line with McArthur (1992, p.491) states that "hyperbole is a rhetorical term for exaggeration or overstatement, usually deliberate and not meant to be 
ENGLISH REVIEW: Journal of English Education Vol. 5, Issue 1, December 2016

taken (too) literally." One of

hyperboles which be the sample was:

Utterance 29 (07:27)

- "Indian people has been in South Africa for like six, seven generations now."

The sentence was overstatement word. How can Russell Peters know that Indian people lived in South Africa until seven generations while he was born in 70's. Chunqi (2014) explains that the function of hyperbole used in stand-up comedy is to exaggerate reality by carrying beyond the boundaries of rational thought. In line with what Kokemuller (2001) says that "some figurative language is used to expand beyond the literal narrative in the story. Hyperbole is a grossly exaggerated or excessive claim." By overstating the word, audience's mind will be opened because the meaning of the word has been expanded from the ordinary word. So, In stand-up comedy hyperbole used to expand meaning.

\section{Idiom}

The fourth function of figurative language in stand-up comedy which will be presented is idiom. Idiom is a figure of speech in figurative language which represents uniquely.

"An expression unique to a language, especially one whose sense is not predictable from the meanings and arrangement of its elements" (McArthur, 1992, p.497). In stand-up comedy, idiom used to make the audiences think deeply about what of stand-up comedian real utterance meaning. Therefore, they will be curious and impressed because of the moral lesson in idiom sentence itself. Idiom has a same function like
ISSN 2301-7554

https://journal.uniku.ac.id/index.php/ERJEE

hyperbole, because the word which is used is not ordinary and has more meaning. One of idioms which be the sample was:

\section{Utterance 12 (04:22)}

- "I wouldn't want my mom to pick my clothes!"

That sentence means Russell has been adult and know what he can do and choose for his life. The sentence was trying to make a word has more than one meaning. By using that sentence, audience's will be interested, focussed and trying to interpret the sentence because the sentence has an expand meaning function. So, idiom used to expand meaning.

\section{Irony}

The fifth function of figurative language in stand-up comedy which will be presented is irony. "...words with an implication opposite to their usual meaning, ironic comment may be humorous or mildly sarcastic" (McArthur, 1992, p.532). In that standup comedy show, most of irony statement told about the way Russell gave an ironic statement when he told stories about ethnic cases between Chinese people and Indian people, White people and Black people etc. One of ironies which be the sample was:

Utterance 47 (11:37)

- "Chinese people and Indian people cannot do business together. Cos Indian cannot live without a bargain and Chinese people cannot give you a bargain."

That sentence heard sarcasm but humorous. Because of Indian people and Chinese have same characteristic they can convince someone to be wrong in selling and buying event. 
So, they couldn't be united in selling and buying event. Russell wanted to amuse audiences by stating the popular issue in the society in that moment in ironic way. As the result, almost the audiences involved in the room and laugh although Russell told stories about certain ethnics issue in ironic way. So, the function of irony in stand-up comedy here were to infer the speaker's intention and to amuse people in comedic situations.

\section{Litotes}

The sixth function of figurative language in stand-up comedy which will be presented is litotes. Litotes is a figure of speech in figurative language which almost has same function like irony. "Litotes is a positive and often emphatic statement made by denying something negative" (Mc.Arthur, 1992, p.622). Litotes is an ironic understatement that uses a negative statement. It is the opposite of irony. If the irony states something bad with the good statement in ironic way, litotes states something good by using negative statement in order to make the statement friendly and down to earth. One of litoteses which be the sample was:

\section{Utterance 107 (27:21)}

- "We know it's not the coolest accent in the world, you know"

That sentence showed understatement of the word which tells about that Indian people knew their accent was unique when they use English. Russell used negative statement to tell audience that Indian accent is not full bad, it is just unique and different from others. The statement is used more humble than in irony by understatement the word. Litotes in that stand-up comedy almost has a same function but they have a different role. Litotes is more positive than irony although it uses understatement word. So the function of litotes is similar like irony. It used to infer the speaker's intention and to amuse people in comedic situations.

\section{Metaphor}

The seventh function of figurative language in stand-up comedy which will be presented is metaphor.

Metaphor is one of rhetorical devices in figurative language which uses comparison statement to make the word is interpreted clearly. "A figure of speech which concisely compares two things by saying that one is the other" (McArthur, 1992, p.653).

Kokemuller (2001) states that using metaphor and simile is a simple way making a statement about a person, place or thing interpreted clearly. These tools allow you to make the point by comparing one thing to another. By using metaphor, a sentence will be created lively and will make audiences understand easily about satnd-up comedian word. When audiences seemed to be easier in comprehending stand-up comedian speech, the situation will be created between audiences and standup comedian is more lively. One of metaphors which be the sample was:

\section{Utterance 164 (40:45)}

- "Yes I can. She's a jackass." In that sentence, Russell tried to compare Ryan's mother with jackass although the comparison word (like, as) was not shown. The example showed that by using figurative some utterances in a language would be presented in expressive way because it uses the broader word. So, it will be 
clearer than the bland statement. By using figurative some utterances in a language would be presented in expressive way because it used the broader word. It would be clearer than the bland statement. So, the function of metaphor was to make a life of stand-up speech in stand-up comedy performance.

\section{Metonymy}

The eighth function of figurative language in stand-up comedy which will be presented is metonymy. Crystal (1994) says in metonymy, symbol of a language or something is used. "Metonymy is used to present a moral lesson or broader point by having a noun in the story represent something beyond the story" (Kokemuller, 2001). One of metonimies which be the sample was:

\section{Utterance 36 (09:36)}

- "Glad to see brown people in the audience."

Brown in that statement refered to Indian people. When Russell said 'Brown people' in that statement, the audiences would think who is brown people. So, audiences will try to extend their thought about that reference. It means the function of metonymy in stand-up comedy is to expand meaning.

\section{Onomatopoeia}

The ninth function of figurative language in stand-up comedy which will be presented is onomatopoeia. As we know, figurative language was used in literary works in order to make the language become imaginative and give different insight. Because of that, the purpose of giving a creative addition in here was needed.
In creative works, some figurative language tools simply increase the creativity of the writing. Imagery is one of the simpler elements to understand. It is the use of descriptive, expressive language to give the reader a mental image (Kokemuller, 2001). In the onomatopoeia utterances, Russell showed his skill in mimicking many accents of some ethnics in the world. One of onomatopoeias which be the sample was:

\section{Utterance 129 (30:57)}

- Cause you're saying stuff like "Fuuuckkk asss!" (with donkey sound) "Buuuulshiiit!" "Yee haw! Yee haw!"

In that statement, Russell was mimicking Donkey's sound when he told about the way Canadian people curse to someone. It sounded like donkey sound. By using that sound, Russell was seen to give a creative addition to his stories. So, his stories will draw audience's attention. By showing that skill, it is shown that the function of onomatopoeia is to give a creative addition.

\section{Personification}

The tenth function of figurative language in stand-up comedy which will be presented is personification. Like in "metonymy is used to present a moral lesson or broader point by having a noun in the story represent something beyond the story" (Kokemuller, 2001). "Personification is used to give human qualities to an object or animal" (Kokemuller, 2001). Personification helps to relate ideas and objects to people, allowing an author to convey his meaning more effectively. One of personifications which be the sample was: 
Utterance 131 (31:33)

- "This is nice room tonight, you know."

In that statement 'room' as inaminate object is given human characteristics by using 'nice' word. Russell tried to give an image about his feeling in that show when he saw many people in stand-up comedy show's room. Turner (2016) says that "figurative language can be used, however, to explain abstract emotions such as love, grief, envy and happiness. Besides to expand meaning, personification used in stand-up comedy to explain abstract emotions when a stand-up comedian in telling story. If it concluded, the function of personification in stand-up comedy was to expand meaning and to explain abstract emotions.

\section{Simile}

The eleventh function of figurative language in stand-up comedy which will be presented is simile. Simile uses a form of comparison in which one thing is compared to another unlike thing by using specific words of comparison like: like, as in order to explain the word clearly by comparing it to another. Simile has a similar function like metaphor. but difference is the using of comparison word is in direct or indirect way. One Both of the examples made the bland statements become colorful because it was presented in expressive way. One of similes which be the sample was:

\section{Utterance 130 (31:00)}

- "White people, when you swear you sound like donkeys"

That sentence showed the way Russell wanted to make the situations in the stand-up comedy show's live by using simile word. He stimulated audience's attention by making comaprison word. In line with Chunqi (2014) says that simile is used to make analogy statement in standup comedy more interesting and unexpected to the live audience. So, the function of simile in stand-up comedy is to a life of stand-up speech in stand-up comedy performance. From the explanation above, it was concluded and found that the functions of figurative language used in stand-up comedy are: first, Alliteration and Onomatopoeia were used to give a creative addition. Second, the function of Chiamus was to make sentence represented in interesting way. Third, Hyperbole, Idiom, Metonymy and Personification were used to expand meaning and to explain abstract emotions. Fourth, Irony and Litotes were used to infer the speaker's intention and to amuse people in comedic situations. Fifth, Simile and Metaphor were used to make a life of stand-up comedy speech in stand-up comedy performance.

As mentioned before, this research tried to reveal the analysis of figurative language in English stand-up comedy. Stand-up comedy show video which was used as the data source was the video of Russell Peters - Comedy Now! Uncensored (2006) stand-up comedy show. In that video, Russell used various form of figurative languages to make his utterances was interesting. To reveal figurative language phenomenon, in this subsections the writer tried to explain clearly the conclusion and the discussion which were gotten from the finding data in this present study.

After analyzing the data, it was concluded that both of main research questions answered clearly. The first research question which told about types 
ENGLISH REVIEW: Journal of English Education Vol. 5, Issue 1, December 2016
ISSN 2301-7554

https://journal.uniku.ac.id/index.php/ERJEE of figurative language were used in standup comedy were figured out. By using McArthur's theory (1992) and Crystal's theory (1994), there were found eleven types of figurative language from 167 utterance. The types were Alliteration, Chiasmus, Hyperbole, Idiom, Irony, Litotes, Metaphor, Metonymy, Onomatopoeia, Personification and Simile. Euphemism, Oxymoron and Paradox were not found in the video of Russell Peters - Comedy Now! Uncensored (2006) stand-up comedy show. The most dominant of figurative language was Irony with the number of occurrences was 50 (29.94\%) and the less figurative language was Litotes with the number of occurrences was $2(1.20 \%)$. In the video of Russell Peters Comedy Now! Uncensored (2006) standup comedy show, Russell Peters used irony as the most figurative language used in his show. Probably, Russell used an ironic statement as the most dominant figurative language in his speech because he has a particular purpose and wanted to deliver his stories in stand-up comedy show in unique way. In line with what Chunqi (2014) states that Joe Wong as one of stand-up comedian in his research used the most frequently figurative language like irony, hyperbole to convey ironies expression about ethnic and culture topic, to attract audience's attention and to provoke laughter. Hyperbole took in the second place as the most dominant of figurative language used by Russell Peters in 40 utterances $(23.95 \%)$. By using the Hyperboles also, probably the joke becomes indirect and less aggressive in attacking the target. In the video of Russell Peters - Comedy Now! Uncensored (2006) stand-up comedy show, Russell told various topics in society. The topics were about ethnics (canadian, white people, black people, brown people and asian), society case (beating child) and culture (accent and life style of various ethnics in the world, habitual of various ethnics in the world). Russell told about ethnic topic by using general characteristic, like white people, brown people, etc. In stand-up comedy, the techniques is called as stereotypes ethnic. In line with Setyaningsih (2013), in her journal about Ethnic Stereotypes in Stand-up Comedy, she stated that to minimize the negative impact in telling ethnic issue in stand-up comedy show, ethnic stereotypes could be used to make the jokes more smooth. In this present study, figurative language in the form Irony and Hyperbole used to make ethnic issue stories told in safe way but still invited audiences to laugh. By using ethnic topics and mix with Irony statement and positive Hyperbole statement, Russell hoped that expression could draw audience's attention in safe way. In conclusion, probably when Russell told about ethnic topic in Irony way and Hyperbole way, the jokes becomes smooth and indirect but still make audience to laugh and draw audience's attention. Because of that, Irony is used dominantly by Russell Peters in his stand-up comedy show. Litotes was the less figurative language used by Russell Peters in that stand-up comedy. Litotes is an ironic understatement that uses a negative statement. It is the opposite of Irony. If the Irony states something bad with the good statement in ironic expression, Litotes states something good by using negative statement in order to make the statement friendly and down to earth. In that stand-up comedy, Russell didn't tell much his stories in litotes way perhaps because his main topics in that stand-up comedy show were about ethnics. He wanted to tell it much in ironic way than in litotes way to make the stories became 
funnier in front of the audiences. So, litotes became the less figurative language which was used in Russell Peters - Comedy Now! Uncensored (2006) stand-up comedy show.

The second research question which told about the functions of figurative language were used in standup comedy were figured out. All of function of stand-up comedy could be concluded by using Chunqi's theory (2014) and supported by Kokemuller's theory (2001) and Turner's theory (2016). In his journal, Chunqi (2014) told about linguistic perspective used by two standup comedian in delivering humour on the stage. One of stand-up comedian there, used figurative language to make his performance draw audience attention and make audience to laugh. In his journal, it was found that just Irony, Hyperbole, Simile and Metaphor were types of figurative language that could make jokes became funny. Moreover, the function of figurative language which were found were just limited to the fourth types. In this present study, because 11 (eleven) types of figurative language were found, this present study was developed from Chunqi's journal (2014). The function of eleven types of figurative language which were used by Russell was concluded. The functions are to amuse people in comedic situations, to expand meaning, to explain abstract emotions, to make sentence represented in interesting way and give creative additions. Each function was shown in different types of figurative language used by Russell Peters. The first function is shown through the using of Irony and Litotes in that stand-up comedy. Most of Irony statement in that stand-up comedy told about the way Russell gave an ironic statement when he told stories about ethnic cases between Chinese people and Indian people, the function of Irony and
Litotes in stand-up comedy here were to infer the speaker's intention and to amuse people in comedic situations. The next function can be found in the using of Hyperbole, Metonymy and Personification. The function of Hyperbole, Idiom, Metonymy and Personification were to expand meaning. When telling about ethnic stories, each functions of figurative language were shown clearly. Beside to expand meaning, figurative language also can be used to explain abstract emotions and creative additions in the speech of standup comedian.

The next function can be shown through the using of Metaphors and Similes. Metaphors and Similes in Russell's utterance made the bland statements become colorful because it is presented in expressive way. By using figurative some utterances in a language would be presented in expressive way because it used the broader word. It would be clearer than the bland statement. So, the function of Simile and Metaphor here were to make a life of stand-up speech in stand-up comedy performance. The next function can be shown through the using of Chiasmus. Russell made a Chiasmus sentence or phrase in which the order of some words in the first sentence or phrase is reversed in the sentence or the phrase that follow. The arrangement of words, phrases and clauses were reversed with a phrase or clause that follows. If we heard a standup comedian used chiasmus, it seemed to be more interesting and easy listening because it used balancing structure. So, the function of Chiasmus is to make sentence represented in interesting way. The last function could be shown through the using of Onomatopoeia and Alliteration in that stand-up comedy show. As we know, figurative language was used in literary works in order to 
ENGLISH REVIEW: Journal of English Education Vol. 5, Issue 1, December 2016

make the language become imaginative and give different insight. Because of that, the purpose of onomatopoeia and alliteration in that stand-up comedy were to give a creative addition.

\section{CONCLUSION}

This study investigates figurative language in English stand-up comedy show. Figurative language as one of the communication strategies is used by people to express the inner feeling and to make the communication more expressive, imaginative and colorful. After analyzing one of selected videos of Russell Peters's stand-up comedy show in chapter 4 , the writer found many particular ways and complex sentences to express the conclusion. The conclusion is based on the research question, that is what are types of figurative language found in stand-up comedy and what are the functions of figurative language used in stand-up comedy. From this study, it is concluded that Russell as the stand-up comedian in the selected video of stand-up comedy used various figurative language. There were 11 (eleven) types of figurative language which were used. The types were Alliteration, Chiasmus, Hyperbole, Idiom, Irony, Litotes, Metaphor, Metonymy, Onomatopoeia, Personification and Simile. From 167 utterance contained figurative language, there were 7 utterances (4.20\%) belonging to Alliteration, 8 utterances $(4.80 \%)$ belonging to Chiasmus, 40 utterances (23.95\%) belonging to Hyperbole, 9 utterances $(5.38 \%$ ) belonging to Idiom, 50 utterances (29.94\%) belonging to Irony, 2 utterances $(1.20 \%$ ) belonging to Litotes, 3 utterances $(1.80 \%)$ belonging to Metaphor, 18 utterances $(10.77 \%)$ belonging to Metonymy, 16 utterances $(9.58 \%)$ belonging to Onomatopoeia, 3 utterances $(1.80 \%)$ belonging to Personification and 11 utterances $(6.58 \%)$ belonging to Simile.
ISSN 2301-7554

https://journal.uniku.ac.id/index.php/ERJEE

From the percentage above we can see that the most dominant of figurative language was Irony with the number of occurrences was 50 (29.94\%). The less figurative language was Litotes with the number of occurrences was $2(1.20 \%)$.

Russell Peters used Irony as the most figurative language used in his show. Russell wanted to deliver his stories in stand-up comedy show in unique way by make an irony statement combined with positive hyperbole statement almost in every utterance. Hyperbole also took in the second place as the most dominant of figurative language use by Russell Peters in 40 utterances $(23.95 \%)$. By using the hyperboles, the joke becomes indirect and less aggressive in attacking the target. In the video of Russell Peters Comedy Now! Uncensored (2006) standup comedy show, Russell told various topics in society. The topics were about ethnics (canadian, white people, black people, brown people and asian), society case (beating child) and culture (accent and life style of various ethnics in the world, habitual of various ethnics in the world). Russell told about ethnic topic in irony way and hyperbole way, to make the jokes becomes smooth and indirect. Because of that, Irony is used dominantly by Russell Peters because he wanted to attract audience attention. In conclusion, probably by using ethnic topics and mix with irony statement and positive hyperbole statement, Russell hoped that expression could draw audience's attention, made the irony statement become smooth and provoked audience's laughter.

Litotes was the less figurative language used by Russell Peters in that stand-up comedy. In that stand-up comedy, Russell didn't tell much his stories in litotes way because his main topics in that stand-up comedy show 
were telling about ethnics issue in interesting way. He wanted to tell it much in ironic way than in litotes way to make the stories became funnier in front of the audiences.

The functions of figurative language found in the selected video of stand-up comedy are:

- Alliteration and Onomatopoeia were used to give a creative addition in Russell's utterance.

- Chiasmus was used to make sentence interesting represented.

- Hyperbole, Idiom, Metonymy and Personification were used to expand meaning.

- Irony and Litotes were used to infer the speaker's intention and to amuse people in comedic situations.

- Simile and Metaphor were used to make a life of stand-up speech in stand-up comedy performance.

Thus, figurative language in this world has various types. The types can be found in people communication. That language is used to make word widely described and to give a special effect to listener. Many functions and reason can be found when someone uses figurative language in communication. The functions itself can come from the situation in communication, etc. But the most domminant function is created from the needs of people itself in communication.

\section{REFERENCES}

Anonymous. Figurative language, Retrieved from http:/ / figurativelanguage.net/

Anonymous. Russell Peters comedy now uncensorred (2006). Retrieved from https://www.youtube.com/watch?v= CPyyt0TmQjk

Anonymous. Russell Peters. Retrieved from https://en.wikipedia.org/wiki/Russe 11_Peters

Astuti, P., Sada, C., \& Wardah. (2013). An analysis of students' perception towards stand-up comedy in speaking spoof monologue. English Language Education Study Program of FKIP Untan. 1-13. Retrieved from jurnal.untan.ac.id/index.php/jpdpb/a rticle/view/6872.

Chunqi, L. (2014). Two Immigrant Humor Styles of Stand-up Comedy (A Linguistic Perspective). International Conference on Education, Language, Art and Intercultural Communication (ICELAIC 2014), 176 - 279. Hebei Vocational College of Foreign Languages, Qinhuandao China: Atlantis Press. Retrieved from http://www.atlantispress.com/php/download_paper.php \%3Fid\%3D12518\&ved=0ahUKEwig38 2kPnMAhUCKpQKHYvBAhMQFggc MAA\&usg=AFQjCNHSJUfKHyX6am TGChFJxD8gbIC6xA\&sig2=bLBbdET1 JaEtMS1GDnN6ig

Cresswell, J. W. (2012). Educational research: Fourth edition. Lincoln: Univesity of Nebraska.

Crystal, D. (1994). The cambridge encyclopedia of the English language. New York: Cambridge University Press.

Fenner, S. (2003). One way communication: definition, advantages \& example. Retrieved from http:/ / www.study.com/academy/les son/one-way-communicationdefinition-advantages-examples.html

Fitri, F.R. (2013). Discourse of Chinese Indonesia in Ernest Prakasa's show in stand-up comedy. Alussion Publication, 2(2), 21-28. Retrieved from journal.unair.ac.id.

Kokemuller, N. (2001). What's the purpose of figurative language. Retrieved from http://classroom.synonym.com/what s-purpose-figurative-language21752.html

Kothari, C.R. (2004). Research methodology (Second revised edition). New Age International.

McArthur, T. (1992). The oxford companion to the English language. New York: Oxford University Press. 
ENGLISH REVIEW: Journal of English Education Vol. 5, Issue 1, December 2016

Oktoma, E., \& Mardiyono, S. (2013). The analysis of presupposition in the short stories of silvester goridus sukur.

English Review: Journal of English Education, 2(1), 76-86.

Setyaningsih, N. (2013). Ethnic Stereotypes in Stand-up Comedy. Faculty of Humanities, Dian Nuswantoro University, Semarang. Prosiding The $5^{\text {th }}$ International Conference on Indonesian Studies "Ethnicity and Globalization." 144 - 157. Retrieved from https://iccssis.files.wordpress.com/20 13/09/2013-02-

13.pdf\&ved=0ahUKEw19tvbw-
ISSN 2301-7554

https://journal.uniku.ac.id/index.php/ERJEE

LMAhWBrI8KHVJDCSkQFggaMAA\& usg=AFQjCNFiiWmU7ledU_ro_HSTG 9d0FffsZA\&sig2=x07BV_dvLC6NbVV K7O3wpQ

Turner, L. L. (2016). What's the purpose of figurative language. Retrieved from http://education.seattlepi.com/whats -purpose-figurative-language5137.html

Yuri. A, R., \& Rosa, R. N. (2013). An analysis of types of figurative language used in internet advertisement. FBS

Universitas Negeri Padang, 72 - 79.

Retrieved from ejournal.unp.ac.id 


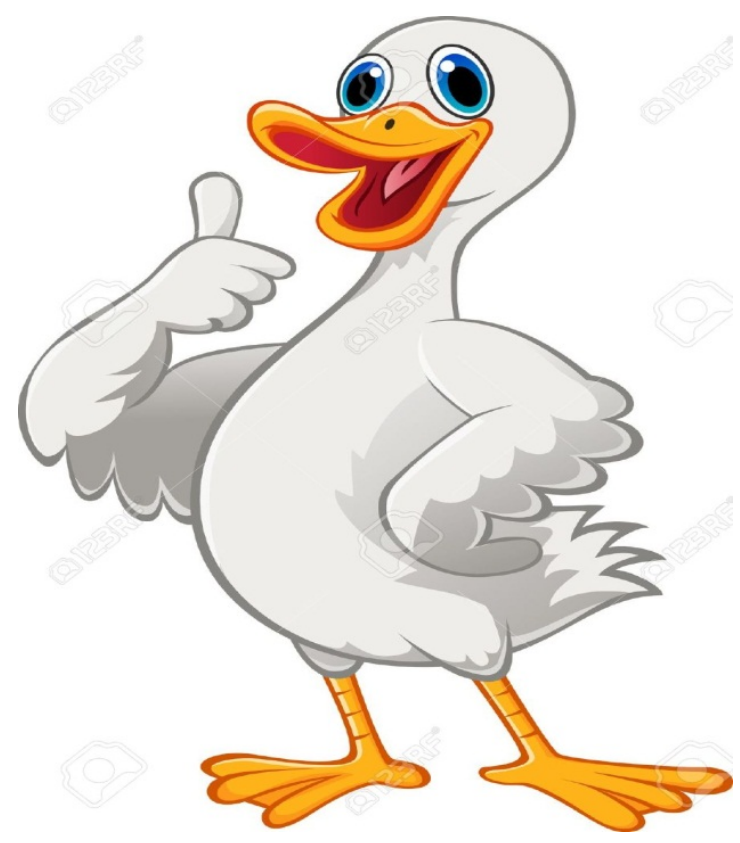

\section{Duck}

A duck walks into a feed store and asks, "Got any duck feed?" The clerk tells him, "No, we don't have a market for it so we don't carry it." The duck says, "Okay," and leaves. The next day, the duck again walks in to the feed store and asks, "Got any duck feed?" Again the clerk says no and the duck leaves. Next day, the duck once again walks in, and asks, "Got any duck feed?" The clerk says, "I've told you twice, we don't have duck feed, we've never had duck feed and we never will have duck feed. If you ask me again, I'll nail your feet to the floor." The duck leaves. The next day, the duck walks in and asks, "Got any nails?" "No." "Got any duck feed?"

(Source: http://www.study-express.ru/humour/funny-stories.shtml 